The University of Maine

DigitalCommons@UMaine

Publications

Senator George J. Mitchell Center for Sustainability

Solutions

$1-2017$

\title{
The Relative Importance of Aquatic and Terrestrial Variables for Frogs in an Urbanizing Landscape: Key Insights for Sustainable Urban Development
}

Nélida R. Villaseñora

Australian National University

Don A. Driscoll

Deakin University, Australia

Philip Gibbons

Australian National University

Aram J K Calhoun

University of Maine, Calhoun@maine.edu

David B. Lindenmayer

Australian National University

Follow this and additional works at: https://digitalcommons.library.umaine.edu/ mitchellcenter_pubs

Part of the Zoology Commons

\section{Repository Citation}

Villaseñora, Nélida R.; Driscoll, Don A.; Gibbons, Philip; Calhoun, Aram J K; and Lindenmayer, David B., "The Relative Importance of Aquatic and Terrestrial Variables for Frogs in an Urbanizing Landscape: Key Insights for Sustainable Urban Development" (2017). Publications. 111.

https://digitalcommons.library.umaine.edu/mitchellcenter_pubs/111

This Article is brought to you for free and open access by DigitalCommons@UMaine. It has been accepted for inclusion in Publications by an authorized administrator of DigitalCommons@UMaine. For more information, please contact um.library.technical.services@maine.edu. 
The relative importance of aquatic and terrestrial variables for frogs in an urbanizing landscape: Key insights for sustainable urban development

Nélida R. Villaseñor ${ }^{\mathrm{a}, *}$, Don A. Driscoll ${ }^{\mathrm{a}, \mathrm{b}}$, Philip Gibbons ${ }^{\mathrm{a}}$, Aram J.K. Calhoun ${ }^{\mathrm{c}}$, David B. Lindenmayer ${ }^{\mathrm{a}, \mathrm{d}, \mathrm{e}}$

${ }^{a}$ The Fenner School of Environment and Society, The Australian National University, Canberra, ACT, 2601, Australia

${ }^{\mathrm{b}}$ School of Life and Environmental Sciences, Centre for Integrative Ecology, Deakin University, Geelong, Melbourne Burwood Campus, 221 Burwood Highway, Burwood, VIC, 3125, Australia

${ }^{\mathrm{c}}$ Department of Wildlife, Fisheries, and Conservation Biology. University of Maine, Orono, ME, 04469, USA

${ }^{\mathrm{d}}$ Long-term Ecological Research Network, Terrestrial Ecosystems Research Network, The Australian National University, Canberra, ACT, 2601, Australia

${ }^{\mathrm{e}}$ ARC Centre of Excellence for Environmental Decisions, The Australian National University, Canberra, ACT, 2601, Australia

* corresponding author

E-mail addresses: nelida.villasenor@anu.edu.au (N.R. Villaseñor), d.driscoll@deakin.edu.au (D.A. Driscoll), philip.gibbons@anu.edu.au (P. Gibbons), calhoun@maine.edu (A.J.K. Calhoun), david.lindenmayer@anu.edu.au (D.B. Lindenmayer). 
Highlights

- Common frog species were associated with the quality of local aquatic habitat.

- Infrequently encountered frogs steeply declined as road length within $1 \mathrm{~km}$ increased.

- A few common frogs can be conserved by providing suitable aquatic environments.

- Aquatic habitat within forest reserves may help conserve urban-sensitive amphibians.

- Management of habitat and land use planning are needed for amphibian conservation. 


\section{ABSTRACT}

Globally, urbanization threatens $\sim 950$ amphibian species with extinction. Yet a lack of knowledge on the factors influencing common and infrequently encountered species in landscapes that are under increasing pressure from urban development is limiting effective conservation. We examined the relative importance of aquatic variables (pond) and terrestrial variables (at three spatial scales: $10 \mathrm{~m}, 100 \mathrm{~m}$ and $1 \mathrm{~km}$ ), for commonly and infrequently encountered frogs in an urbanizing forested landscape in southeastern Australia. Species richness and the occurrence of four common species were influenced by the aquatic environment (water body size, aquatic vegetation). Species richness also decreased with increasing urbanization within $1 \mathrm{~km}$. This trend was driven by a strong decrease in richness of infrequently encountered species with increasing road length within $1 \mathrm{~km}$ from breeding ponds. Richness of infrequently encountered species also decreased with a reduction in forest cover within $10 \mathrm{~m}$ to $1 \mathrm{~km}$ from breeding ponds. Our findings suggest that frog conservation in urbanizing landscapes requires a mix of strategies across different spatial scales. Maintaining or re-establishing common frogs in urbanizing forested landscapes is likely to be achieved by providing ponds with suitable habitat. However, to conserve several frog species that are sensitive to forest loss and urbanization, breeding habitats need to be maintained within a network of large forest reserves.

Keywords: Common and rare species, Crinia signifera, Litoria peronei, Limnodynastes peronei, Pond-breeding amphibians, Forest-urban gradient 


\section{Introduction}

As the human population increases, a better understanding of how amphibian species respond to urbanization is needed worldwide. Urban human populations will increase by 2.7 billion from 2010 to 2050 (United Nations, 2012). Therefore, development for residential purposes will continue modifying landscapes and threatening biodiversity in many regions of the world (Beninde, Veith, \& Hochkirch, 2015; McDonnell \& Hahs, 2015; Villaseñor, Blanchard, \& Lindenmayer, 2016). Among vertebrates, amphibians are the most threatened group: about 40\% of amphibian species are threatened with extinction and the average size of populations has declined by up to $80 \%$ in the last four decades (based on 357 populations of 162 species from around the world; Baillie, Griffiths, Turvey, Loh, \& Collen, 2010). Given that urban development threatens about 950 amphibian species with extinction (Baillie et al., 2010; Hamer \& McDonnell, 2008), how can we conserve amphibians in an urbanizing world?

Amphibians rely on aquatic environments for breeding and larval development, and on terrestrial environments during juvenile and adult stages (Anstis, 2007; Semlitsch \& Skelly, 2008). Thus, attributes of aquatic and terrestrial environments can affect amphibian distributions. Key variables from the aquatic environment influencing amphibian distributions include water body size, hydroperiod (i.e., period covered by water), the presence of fish and aquatic vegetation. Larger water bodies can support higher species richness (Parris, 2006). Hydroperiod can influence the species inhabiting a wetland (e.g., in ephemeral pools; Baldwin, Calhoun, \& deMaynadier, 2006; Semlitsch, 2000). Predatory fish can have detrimental effects on amphibians 
(Shulse, Semlitsch, \& Trauth, 2013), whereas aquatic vegetation may provide refuge against predation during amphibian larval stages (Hamer \& Parris, 2011).

Modification of terrestrial environments, such as clearing of vegetation for urban development, can lead to habitat loss and fragmentation (Hamer \& McDonnell, 2008; Semlitsch \& Skelly, 2008), and influence amphibian populations from local to landscape scales (Hamer \& Parris, 2011). Important variables from the terrestrial environment influencing amphibian distribution include fringing vegetation (i.e., vegetation adjacent to waterbodies), as well as forest cover and urban infrastructure at different landscape scales. At the local scale, fringing vegetation provides refuge for metamorphs and breeding adults (Hazell, Cunnningham, Lindenmayer, Mackey, \& Osborne, 2001). Forest loss reduces terrestrial habitat for adults and leads to decreased richness, occurrence and abundance of several amphibian species (Ficetola, Marziali, Rossaro, De Bernardi, \& Padoa-Schioppa, 2011; Hamer \& McDonnell, 2008). Increased road cover, a surrogate variable for urbanization (Hamer \& McDonnell, 2008), may reduce connectivity and isolate populations by limiting dispersal and migration between breeding habitats (Eigenbrod, Hecnar, \& Fahrig, 2008; Hitchings \& Beebee, 1997).

Urbanization may be an important anthropogenic driver of species loss in terrestrial landscapes, because only a few species able to adapt to rapid urbanization prevail (McDonnell \& Hahs, 2015). Thus, management derived from ecological studies in urban landscapes may be biased towards a few common species that are recorded in sufficient numbers to perform statistical analysis. If management of landscapes under high human pressure is based on findings from 
these species, it may fail to cater for the needs of species at a higher risk of decline - such as previously common species that become locally-extinct or infrequently encountered as a result of habitat modification (Gaston \& Fuller, 2007).

Increased urbanization of natural and rural lands can pose a serious threat to amphibians. However, our ability to guide conservation efforts remains limited because amphibians are among the least studied vertebrate groups in urbanizing landscapes (McDonnell \& Hahs, 2008). Although the number of studies of amphibians in urban areas and in landscapes under urban development is growing, planners and managers still lack information to effectively guide amphibian conservation in most urbanizing landscapes worldwide (but see Calhoun, Jansujwicz, Bell, \& Hunter, 2014).

To provide conservationists, managers and urban planners with empirical insights to guide effective conservation of common and infrequently encountered amphibian species in urbanizing landscapes, we studied the distribution of pond-breeding frogs during the breeding season in a landscape comprised of forests, rural, and urban areas in southeastern Australia. Population growth and increased demand for holiday houses are triggering forest clearing for urban development in the region, but little is known about how this development affects the native fauna of the area. Currently, it is not known whether local environmental attributes or landscape context are the key factors that influence amphibian communities. The uncertain viability of approximately $96 \%$ of frog species in this region (State of the Environment 2011 Committee, 2011) demands urgent insights on the effects of urbanization on frogs to guide conservation 
actions. We asked: How is the distribution of pond-breeding frogs during the breeding season influenced by aquatic variables (water body size, aquatic vegetation, and presence of fish), and terrestrial variables (local habitat structure, and, at two spatial scales, forest and road cover)? In particular, we aimed to answer the following three key research questions:

Q1. Are common species (occurrence $\geq 36 \%$ of surveyed ponds) influenced by aquatic habitat, terrestrial habitat, or both? This knowledge will allow us to plan and manage urban areas to maintain common species.

Q2. What are the main factors (from the aquatic and terrestrial environments) influencing species richness of infrequently encountered pond-breeding frogs? If infrequently encountered frogs (occurrence $<35 \%$ of surveyed ponds) are influenced by local-scale variables, conservation strategies can aim to improve local habitat condition within urban areas; whereas if they are sensitive to landscape variables, maintaining undisturbed habitat around breeding sites will be important to prevent species loss in urbanizing landscapes.

Q3. Does species richness reflect the variables influencing both common and infrequently encountered species? This is important because frog species richness has been proposed as a focus for conservation management in Australian urban environments (e.g., Hamer \& Parris, 2011). 
Knowledge of which variables from the aquatic and terrestrial environment influence amphibian distributions in urbanizing landscapes will help guide management and urban planning to conserve both common and infrequently encountered species. This knowledge is essential for amphibian conservation in forest ecosystems undergoing urban development worldwide.

2. Methods

\subsection{Study area}

This study was conducted between Nowra $\left(34.86^{\circ} \mathrm{S} 150.60^{\circ} \mathrm{E}\right)$ and Booderee National Park $\left(35.16^{\circ} \mathrm{S} 150.73^{\circ} \mathrm{E}\right)$, and covered approximately $600 \mathrm{~km}^{2}$ in New South Wales, southeastern Australia (Fig. 1). The study area is dominated by native eucalypt forests and wetlands, and rural and urban areas. Rural areas comprised cleared areas for livestock paddocks. Urban areas comprised several small towns of $<10,000$ inhabitants and the Nowra-Bomaderry urban center of $\sim 35,000$ inhabitants (Australian Bureau of Statistics, 2011). The region has a temperate climate, with warm summers and mild winters. Annual mean minimum and maximum air temperatures are $13.8^{\circ} \mathrm{C}$ and $20^{\circ} \mathrm{C}$, respectively. Annual rainfall is approximately $1000 \mathrm{~mm}$ and is spread evenly throughout the year (www.bom.gov.au). 


\subsection{Study design}

\subsubsection{Pond selection}

To study the factors which influence frog richness and individual frog species occurrence in ponds with long hydroperiods (flooded for most part of a breeding season), we visually identified and manually digitalized ponds on a Quickbird image (2008, Google Earth $\left.{ }^{\mathrm{TM}}\right)$ at a resolution of 1:2000. Ponds were stratified based on three land cover types (forest, rural, and urban) to sample ponds in different urbanization levels (McDonnell \& Hahs, 2008), and three water body sizes ( $\leq 50 \mathrm{~m}, 51-100 \mathrm{~m}$ and $>100 \mathrm{~m}$ in diameter). Land cover type was defined by the land cover immediately surrounding the pond. Forest cover comprised forests and woodlands within public and private land, rural cover comprised cleared areas for livestock paddocks, and urban cover comprised residential areas and urban parks within towns and the Nowra-Bomaderry urban center. We randomly selected ten ponds within each land cover type and ensured that different water body sizes $(\leq 50 \mathrm{~m}, 51-100 \mathrm{~m}$ and $>100 \mathrm{~m}$ in diameter) were represented (Fig. 1). Due to problems with access and vandalism, two sites were not surveyed in urban areas (total ponds surveyed $=28$; forest $=10$, rural $=10$, and urban $=8$ ). All ponds were located $>800 \mathrm{~m}$ from each other, which we considered sufficient to reduce autocorrelation because most frog species in our study area were unlikely to travel longer distances during a breeding season (Hamer \& Parris, 2011; Lauck, 2005). 


\subsubsection{Pond-breeding frog surveys}

In our region, most frog species are easily detected by male calls during the breeding season (e.g., November-February; Amphibian Research Centre, 2012; Lemckert \& Mahony, 2008). Although the probability of detecting a frog species at a site can vary within this peak calling activity period, southeastern Australian frogs can be detected at a high rate by using nocturnal aural surveys. For example, Parris (2006) estimated a high (74-99\%) probability of detecting a frog species present in a pond with three visits. Therefore, we recorded frog calls at ponds during the breeding season to maximize detectability. Ponds were surveyed in November 2012 and again in January-February 2013. In each survey period, we recorded frog calls over three nights

at each pond. For this, we placed an automatic recorder (Faunatech ${ }^{\mathrm{TM}}$, Bairnsdale, Victoria) at a pond edge, which recorded four three-minute blocks per night (total recorded time per pond $=36$ min). Each night, recording started at 21:00, 23:00, 01:00 and 03:00 (Smallbone, Luck, \& Wassens, 2011). To avoid confounding the effects of weather with our predictor variables, we surveyed ponds of several sizes and different land cover types simultaneously. We identified species by their calls using reference libraries (e.g., Amphibian Research Centre, 2012).

\subsubsection{Aquatic and terrestrial variables}

We measured aquatic and terrestrial variables considered likely to affect frog distributions. Aquatic variables included water body size, percentage cover of surface vegetation (sum of emergent and floating vegetation) and presence of eastern gambusia (Gambusia holbrooki)—an 
exotic fish species that can negatively affect frog populations (Shulse et al., 2013) (Table 1). We estimated water body size and surface vegetation cover visually, but calculated water body size in ArcGIS (ESRI) when ponds exceeded $50 \mathrm{~m}$ in diameter to increase accuracy of assessment. To detect the presence of eastern gambusia, we performed a five-minute visual search and placed a 1.25-L bottle trap in large ponds or a $0.5-\mathrm{L}$ bottle trap in small $\left(\sim 1.5 \mathrm{~m}^{2}\right)$ ponds for three days (Hamer \& Parris, 2011).

Terrestrial variables were quantified at both the landscape and local level. Landscape context variables were calculated using ArcGIS. For each pond, we calculated the total road length (including paved and unpaved roads) within $100 \mathrm{~m}$ and $1000 \mathrm{~m}$ buffers using a road shapefile obtained from the Government of New South Wales. In addition, we calculated forest cover within $100 \mathrm{~m}$ and $1000 \mathrm{~m}$ buffers surrounding each pond with a raster of forest cover estimated from Landsat satellite images of 2010-2012 (Department of Environment, 2013). At the local level, we estimated visually within a $10 \mathrm{~m}$ buffer from the edge of the water body, the percentage cover of seven habitat types (i.e., bare ground, grassland, shrubland, woodland (tree crowns are clearly separated), forest (tree crowns touching), scattered trees, rocks, and total fringing vegetation) (Table 1). Variables measured at these scales $(10 \mathrm{~m}, 100 \mathrm{~m}$ and $1000 \mathrm{~m}$ from the breeding habitat) can influence amphibian distributions and provide important insights to guide planning and development around breeding ponds. 


\subsection{Data analyses}

\subsubsection{Detectability of frog species}

To determine if our survey effort allowed us to assert that a species was absent with a high degree of confidence, we first calculated the probability of detecting each frog species after a single visit (one day) (MacKenzie et al., 2002) using the 2012 three-day survey data (Scheele et al., 2014). A single-visit detection probability is the probability of detecting the species during a single-visit to a site where the species is present. For each species, we then calculated the cumulative probability of detecting the species following one, two and three-day surveys (Wintle, Kavanagh, McCarthy, \& Burgman, 2005).

\subsubsection{Predictor aquatic and terrestrial variables}

We summarized variation among ponds for terrestrial variables using metric Multidimensional Scaling (MDS) based on Euclidean distances. Each variable was standardized (by subtracting the variable's mean value and dividing by the variable's mean absolute deviation) before calculating the dissimilarities and a 2-dimensional configuration was used to summarize the data. We did not include road length within $100 \mathrm{~m}$ and $1000 \mathrm{~m}$ in the MDS so we could explore their effects separately. This was because road length around ponds can be used as a surrogate variable for urbanization (Hamer \& McDonnell, 2008). The first MDS axis described a gradient from ponds 
characterized by low forest cover within $10 \mathrm{~m}, 100 \mathrm{~m}$, and $1000 \mathrm{~m}$ and fringing vegetation dominated by grasslands (urban ponds, lower scores), to ponds surrounded by high forest cover within $10 \mathrm{~m}, 100 \mathrm{~m}$ and $1000 \mathrm{~m}$ (forest ponds, higher scores) (Fig. 2, Table 1). Thus, the first MDS axis arranged ponds according to urbanization levels: urban, rural and forests (Fig. 2). Increasing scores in the second MDS axis characterized ponds with more grassland and less bare ground and rocks within the $10 \mathrm{~m}$ buffer, as well as less forest cover within $1000 \mathrm{~m}$ (Fig. 2, Table 1).

\subsubsection{Effect of habitat variables on frog distributions}

We examined the effects of aquatic variables, terrestrial MDS axes and road lengths on total species richness, species richness of infrequently encountered species (detected at $<35 \%$ of surveyed ponds), and individual species occurrences using model selection with Generalized Linear Models (GLMs) (see Sections 2.3.3.1-2.3.3.3). To improve model fit, we transformed predictor variables when needed (Table 1). We confirmed the lack of collinearity between our predictor variables by calculating a correlation matrix and variance inflation factors (VIF; Zuur, Ieno, Walker, Saveliev, \& Smith, 2009). Low collinearity $(r \leq 0.5, \mathrm{VIF}<1.6)$ between predictor variables allowed us to explore their effects separately. We fitted a series of models that included different combinations of the additive effects of: the three aquatic variables, the two axes from MDS from terrestrial variables, and road length within the $100 \mathrm{~m}$ buffer and the $1000 \mathrm{~m}$ buffer. 


\subsubsection{Models for species richness.}

We analyzed total species richness by fitting GLMs with a Poisson distribution (log link). In addition to additive effects, we allowed the first MDS of terrestrial variables to interact with road length within $1 \mathrm{~km}$. In this way, we could distinguish whether the effect of road length within 1 $\mathrm{km}$ on species richness was dependent on the amount of forest cover. All models predicting total species richness included the natural logarithm of the number of surveys as an offset to account for different sampling effort in five of our 28 ponds evaluated (which had one instead of two three-day surveys due to limited access and vandalism). To avoid over parameterizing models, we limited the number of variables to be included in the same model to two, but we also included a model with the interactive effect of the first MDS axis with road length within $1 \mathrm{~km}$, and their main effects. Thus, the candidate set for total species richness included 30 models (Supplementary material, Table S1).

\subsubsection{Models for species richness of infrequently encountered species.}

We also explored relationships between our predictor variables and species richness of infrequently encountered species. We defined 'infrequently encountered' species as those present at $<35 \%$ of surveyed ponds (i.e., $<10$ ponds; Table 2 ). Low occurrence of infrequently encountered species did not allow individual species analysis_-given that at least ten detections (or events) are recommended to model one predictive variable in a logistic regression (e.g., Peduzzi, Concato, Kemper, Holford, \& Feinstein, 1996). A histogram revealed many ponds 
without infrequently encountered species (zero inflation). Thus, we fitted candidate models with negative binomial GLMs and included the natural logarithm of the number of surveys as an offset (Zuur et al., 2009). Given the limited number of ponds with species richness of infrequently encountered species larger than zero $(n=14$ ponds), we restricted the number of predictor variables in a model to two. Thus, the candidate model set for infrequently encountered species richness comprised 29 models (Supplementary material, Table S1).

2.3.3.3. Models for individual species occurrence (common species).

We defined 'common' species as those detected at $\geq 36 \%$ of surveyed ponds $(\geq 10$ ponds; Table 2). Once we confirmed that our common species were detected with a high degree of confidence after three-day surveys (see Section 2.3.1), we fitted GLMs with a binomial distribution (logit link) describing the probability of occurrence of individual species. We used the proportion of occurrence of a species in a pond (e.g., for ponds with two surveys (November and JanuaryFebruary): $0=$ not recorded, $0.5=$ recorded in one survey, $1=$ recorded in both surveys) and the number of surveys over which the proportion of occurrence was calculated was modeled as model weights (binomial glm, R Core Team, 2013). To minimize the number of models we fit, we did not include the second MDS axis (because it was less biologically meaningful than the first MDS axis) and we restricted the inclusion of predictor variables to two within a model. This led to 22 models in the candidate set for each species (Supplementary material, Table S1).

\subsubsection{Model selection.}


We selected the best GLMs from each candidate model set (i.e., total species richness, species richness of infrequently encountered species and individual species occurrence) using an information-theoretic approach, based on Akaike's Information Criterion corrected by small sample size (AICc) (Burnham \& Anderson, 2002). We first assessed overdispersion in models fitted with all our predictor variables for each response variable. We did this by comparing the model residual with the residual degrees of freedom. Only GLMs fitted for Litoria fallax occurrence showed evidence of overdispersion and thus, models for this species were selected with Quasi-AICc (QAICc) instead of AICc (Burnham \& Anderson, 2002). From the set of topranked models (those within 2-AICc or 2-QAICc units from the best model), we disregarded models with uninformative parameters. Models with uninformative parameters are those within 2 AICc-units of a better-ranked model that include one parameter in addition to parameters in the better model. In those circumstances, the new parameter does not explain enough variation to justify its ecological interpretation (Arnold, 2010). Finally, we predicted the individual effect of each explanatory variable from our 'best' models (lowest AICc or QAICc) for each response variable.

All statistical analyses were performed in R-3.0.1 (R Core Team, 2013). We used the function glm.nb in the package "MASS" (Venables \& Ripley, 2002) for fitting negative binomial GLMs; “unmarked” for detectability analyses (Fiske \& Chandler, 2011); "MuMIn” (Barton, 2013) for model selection; and the functions cmdscale and predict.glm in the package "stats" for calculating MDS and to obtain predicted values and standard errors from best models, respectively (R Core Team, 2013). 


\section{Results}

We recorded 14 frog species at 28 ponds (Table 2). All were native species and one (L. aurea) is endangered under state-level legislation (NSW Threatened Species Conservation Act 1995). Five species were recorded in a sufficient number of ponds to allow individual species analysis:

Crinia signifera (71\% of ponds), L. peronii (71\%), Limnodynastes peronii (Lim. peronii from now on; 46\%), Litoria fallax (43\%) and L. tyleri (36\%). Among these common species, the probability of detecting a species on any single visit was highest for L. fallax (Estimate $\pm \mathrm{SE}=$ $0.97 \pm 0.03)$ and lowest for Lim. Peronei $(0.57 \pm 0.13)$. After a three-day survey, the probability of detecting the species with lowest detection ( $\mathrm{Lim}$. peronii) was $0.92(95 \% \mathrm{CI}=0.83-0.97$; Appendix A, Fig. A1). For infrequently encountered species (detected at $\leq 21 \%$ of ponds), the probability of detecting a species with a three-day survey was high, ranging from 0.95 to 0.99 (95\% CI = 0.79-0.99); except for Pseudophryne bibronii (0.04, 95\% CI = 0-0.1). Pseudophryne bibronii is one of the few frog species that breeds during autumn in our region (e.g., March-June; Amphibian Research Centre, 2012) so was not expected to be adequately sampled in our study. Exploratory analyses showed that predictor terrestrial variables varied with urbanization levels, but there was no evidence of bias for predictor aquatic variables in relation to urbanization levels (Supplementary material, Figs. S1-S2). 


\subsection{Species richness}

Total species richness recorded at a pond varied from zero to nine species $($ median $=3.5$

species); whereas species richness of infrequently encountered species recorded at a pond varied from zero to five species (median $=0.5$ species). The best model for total species richness contained two explanatory variables: the natural logarithm of water body size $\left(\beta_{1}=0.14 \pm 0.05\right.$, $P=0.01)$ and the natural logarithm of road length within $1 \mathrm{~km}((32=-0.45 \pm 0.16, \mathrm{P}=0.006$; Table A1, Fig. 3A). That is, there was a positive effect of increasing water body size on total species richness that was most important at small pond sizes and a decline in total species richness with increasing road length within $1 \mathrm{~km}$ (Fig. 3A).

Species richness of infrequently encountered species also declined with increased road length within $1 \mathrm{~km}$, but at a higher rate than total species richness $\left(\beta_{2}=-1.13 \pm 0.37, P=0.002\right.$; Table A1, Fig. 3B). The natural logarithm of road length within $1 \mathrm{~km}$ was an important predictor for species richness of infrequently encountered species, because it was present in the competitive model (within 2- $\triangle \mathrm{AICc}$, Table A1). In addition, species richness of infrequently encountered species increased with the first MDS axis $\left(\beta_{1}=0.2 \pm 0.1, P=0.048\right)$ and thus, it was highest in ponds within forests (positive values for terrestrial MDS-1; Fig. 3B). To confirm that the influence of landscape variables (roads within $1 \mathrm{~km}$ ) on total species richness were due to their influence on infrequently encountered species rather than on common species, we performed a supplemental model selection to evaluate the influence of terrestrial and aquatic variables on common species richness. Our supplemental analysis confirmed that the natural logarithm of 
water body size was the main variable influencing common species richness (Supplementary material, Table S2). Thus, the influence of roads within $1 \mathrm{~km}$ from breeding ponds on total species richness is due to the negative influence of terrestrial variables on infrequently encountered species.

\subsection{Individual species occurrence}

The best models for individual species occurrence revealed that the probability of occurrence for C. signifera, L. peronii and L. tyleri increased with the natural logarithm of water body size (Table A1, Fig. 3C-E). The likelihood of recording C. signifera increased with increasing percentage of aquatic vegetation $\left(\beta_{2}=0.205 \pm 0.1, P=0.04, \Delta \mathrm{AICc}=0\right)$, although the null model was included among the best models $(\triangle \mathrm{AICc}=1.77$; Table A1; Fig. 3C). Litoria peronii occurrence in ponds surrounded by $>100 \mathrm{~m}$ road length was lower than in ponds surrounded by $<100 \mathrm{~m}$ road length within $100 \mathrm{~m}$ buffer $\left(\beta_{2}=-1.45 \pm 0.65, P=0.03\right.$; Table A1; Fig. 3D).

Limnodynastes peronii occurrence increased in ponds with a higher percentage cover of aquatic vegetation $\left(\beta_{1}=0.33 \pm 0.11, P=0.003\right.$; Table A1; Fig. 3F). The best model describing L. fallax occurrence was the null model (Table A1). 


\section{Discussion}

To help guide management and land use planning for amphibian conservation in urbanizing forested landscapes, we examined the relative importance of aquatic and terrestrial variables for pond-breeding frogs during a breeding season in a landscape of forests, rural and urban areas. In line of the three key questions posed at the Introduction, we found:

(1) The occurrence of common frogs was best explained by the local (aquatic) habitat.

(2) The richness of infrequently encountered frog species was best predicted by the terrestrial environment at a large spatial scale, implying that habitat modification as far as $1 \mathrm{~km}$ from breeding habitats may be the key driver of local species loss rather than local-scale modification of individual breeding sites.

(3) Total species richness captured the influence of local habitat on common species as well as landscape variables on infrequently encountered species. But at the species richness level, common species attenuated the steep decline of infrequently encountered species with increasing road length within $1 \mathrm{~km}$ from breeding ponds.

Our findings suggest that management of local habitat may help conserve a few common frog species, but it will fail to conserve many frog species disadvantaged by urbanization of the 
broader landscape. We discuss the influence of aquatic and terrestrial environments on our pondbreeding frogs. In addition, we suggest that conservation guidelines should integrate local-scale management of aquatic habitats and land use planning to maintain both common and infrequently encountered frog species in urbanizing landscapes.

4.1. Local aquatic environment and amphibian distribution

Larger ponds supported higher frog species richness than smaller ponds, and had a greater probability of supporting common species (i.e., recorded at $\geq 36 \%$ of surveyed ponds, such as $C$.

signifera, L. peronii and L. tyleri). However, the benefits of increasing water body size on species richness and the occurrence of common species was more important at small pond sizes (e.g., $<500 \mathrm{~m}^{2}$; Fig. 3). Greater frog species richness with increasing water body size, as well as the greater benefits of increasing water body size at small pond sizes, agrees with findings from other work in our study area (Westgate, Driscoll, \& Lindenmayer, 2012), elsewhere in Australia (Parris, 2006) and worldwide (for a review, see Hamer \& McDonnell, 2008). Some frog species benefit from larger water bodies due to longer hydroperiods, which might provide breeding habitat for a longer time within a breeding season (Westgate et al., 2012). In addition, larger ponds may support higher species richness because they provide a variety of niches and also can support larger populations, reducing extinction rates (Hanski, 1994; Parris, 2006). 
Aquatic vegetation had a limited effect on most frog species. However, it was the most important variable predicting Lim. peronii occurrence. For instance, it was very unlikely to find Lim. peronii in ponds with no surface vegetation (95\% CI: $0.02-0.28)$, but ponds with $80 \%$ of surface vegetation were more likely to support Lim. peronii (95\% CI: 0.41-0.79). Limnodynastes peronii has large egg masses (Table 2) that it lays in floating foam nests concealed in surface vegetation (Anstis, 2007). Thus, aquatic vegetation may provide suitable conditions for $\mathrm{Lim}$. peronii to lay eggs, as well as refuge against predation for both adults and larvae, helping this species to persist in urban landscapes and colonize a variety of urban ponds (Amphibian Research Centre, 2012). We recorded this species in small urban garden ponds, which reveals its tolerance of small breeding habitats, forest fragmentation and residential development compared to other frogs in our study area.

\subsection{Terrestrial environment and amphibian distribution}

The terrestrial variables we measured had limited effects on the occurrence of most common frog species, except for L. peronei, Crinia signifera, Lim. peronii, L. peronii, L. tyleri and L. fallax are widespread species that can tolerate some level of disturbance (Table 2). However, L. peronii was sensitive to urbanization: L. peronii was less likely to occur in ponds surrounded by $>100 \mathrm{~m}$ road length within $100 \mathrm{~m}$ buffer. Despite the positive associations of the genus Litoria with increased urbanization found elsewhere in Australia (Hamer \& Parris, 2011), we found L. peronii was sensitive to urbanization within $100 \mathrm{~m}$ from breeding ponds. 
Urbanization at large spatial scales (within $1 \mathrm{~km}$ of ponds) had negative effects on species richness. Ponds with less surrounding forest and higher road cover within $1 \mathrm{~km}$ supported fewer infrequently encountered frog species. Thus, species richness of infrequently encountered species was highest in forest ponds, lower in rural ponds and lowest in urban ponds (Fig. 3B). In addition, the number of infrequently encountered frog species at a pond declined strongly with small increases in the surrounding road length. This agrees with findings from other urban studies, where breeding sites surrounded by limited forest cover and a large number of roads supported low frog species richness (Hamer \& McDonnell, 2008; Parris, 2006; Simon, Snodgrass, Casey, \& Sparling, 2009). However, the steep rate of decline of infrequently encountered frogs with small increases in road cover within $1 \mathrm{~km}$ was subdued at the species richness level, demonstrating that biodiversity metrics like total species richness may underestimate the impacts of urbanization.

Our findings for infrequently encountered species suggest urbanization is the key factor driving loss of pond-breeding frogs in our region. Urbanization can increase extinction risk of frog populations due to increased mortality on roads and can limit colonization of potential breeding ponds due to increased isolation (Hitchings \& Beebee, 1997; Rytwinski \& Fahrig, 2015). In addition to increased mortality on roads, greater isolation in urban landscapes may be caused by physical barriers (e.g., buildings, fences) and behavioral barriers (e.g., avoidance of impervious surfaces or traffic disturbance) (Eigenbrod et al., 2008; Rytwinski \& Fahrig, 2015). Maintaining breeding habitat within large expanses of undisturbed forest can help frog populations persist by providing terrestrial habitat for juveniles and adults (e.g., upland and non-breeding habitat), 
maintaining local migratory routes between breeding and non-breeding habitats, and promoting connectivity among populations (Hamer \& McDonnell, 2008).

Although we examined only one breeding season, we expect the patterns of occurrence of common and infrequently encountered species we quantified to reflect longer term trends. Other studies have reported the importance of similar variables to those identified in this study which influence frog species richness within our study area (in reserves, Westgate et al., 2012) and in other parts of south-eastern Australia (in urban areas, Hamer \& Parris, 2011; Parris, 2006; Smallbone et al., 2011). In addition, 'normal weather' conditions were recorded for surveyed years. Annual rainfall $>1000 \mathrm{~mm}$ has been recorded in our study area after 2010 (at Sanctuary Point station; www.bom.gov.au), following a dry year in 2009 (713.2 mm). Although we expect some changes to occur over time, we believe the patterns observed in our study are unlikely to be an annual anomaly.

\subsection{Amphibian conservation in urbanizing landscapes}

Our findings highlight that to achieve the conservation of both common and infrequently encountered species in urbanizing forested landscapes, planners must look at both local breeding habitats and the surrounding landscape. Most policies relating to frog conservation focus on immediate habitats surrounding breeding habitats (Calhoun et al., 2014; Semlitsch, 2000). However, our study revealed that decreasing forest cover (at different spatial scales) and increasing road cover within $1 \mathrm{~km}$ of ponds reduces the occurrence of infrequently encountered 
frog species. This mismatch between the scale at which environmental policies define restrictions for development and the scale at which development has detrimental effects on habitat quality for several species raises concern in this study system, and in others (Calhoun et al., 2014; Harper, Rittenhouse, \& Semlitsch, 2008; Semlitsch, 2000).

How can we conserve frog species in urbanizing landscapes? Our findings suggest that in landscapes dominated by forests and where most development leads to the creation or expansion of small urban centers (e.g., $<10,000$ inhabitants), common frogs could travel across terrestrial habitats and inhabit suitable ponds. Conservation of common frogs in these kinds of urban areas may therefore be improved by appropriately managing aquatic habitats. For instance, increasing the water body size of small ponds may benefit frog species richness, as well as the occurrence of C. signifera, L. peronii and L. tyleri. Our species-area curves for common species also suggest that adding or retaining several medium-size (e.g., $\sim 500-5000 \mathrm{~m}^{2}$ ) ponds may result in a greater gain in occurrence or species richness of common species than adding or retaining fewer but larger (e.g., $>5000 \mathrm{~m}^{2}$ ) ponds. In addition, managing ponds so they develop a high percentage of surface vegetation may increase Lim. peronii occurrence; whereas avoiding road development within $100 \mathrm{~m}$ of a pond can increase the likelihood of maintaining L. peronii. These few common species tolerate some level of disturbance and may colonize new ponds or wetlands within rural and urban areas (Lauck, 2005; Parris, 2006); which provides opportunities for conservation of common native species in urban environments as well as environmental education and awareness (Compton, McGarigal, Cushman, \& Gamble, 2007). 
Our results on species richness of infrequently encountered species add to the evidence that urbanization has negative impacts on amphibians. To conserve infrequently encountered frog species at a landscape scale, it is necessary to preserve undisturbed natural vegetation cover within long distances from breeding habitats ( $1 \mathrm{~km}$ in our study). Maintaining ponds within a system of connected reserves may help to reduce the impacts of habitat loss and urbanization on breeding sites, while providing terrestrial habitat and permeable migratory routes (Compton et al., 2007; Harper et al., 2008). Furthermore, because amphibians are particularly susceptible to habitat fragmentation by roads and direct mortality on roads (Rytwinski \& Fahrig, 2015), careful planning and mitigation strategies are needed to reduce road impacts (e.g., fences to direct amphibians to safe passages; Cosentino et al., 2014).

Contrasting responses by common and infrequently encountered frog species highlight the need for management and planning at both local and landscape scales. Incorporating these approaches into policy and practice will require local guidelines for amphibian conservation, long-term monitoring studies and multidisciplinary efforts (Calhoun et al., 2014). For instance, in the USA, local guidelines for forestry and urban development (e.g., best development practices; Calhoun, Nicholas, \& Klemens, 2005); as well as local solutions to conserving pool landscapes (Calhoun et al., 2014) have been established to maintain amphibian populations and their habitats in the face of urbanization. In addition, tools for spatial planning (e.g., Baldwin \& deMaynadier, 2009) can help to integrate scientific evidence into landscape planning for amphibian conservation. 


\section{Conclusions}

What are the variables from aquatic and terrestrial environments that common and infrequently encountered species respond to? The key discovery in this study was that during the breeding season, common frogs responded to local aquatic variables (pond size and surface vegetation) whereas infrequently encountered frog species were highly sensitive to modification of the broader terrestrial environment. Managing ponds for appropriate water body size and a high percentage cover of surface vegetation may increase species richness by increasing the occurrence of common species, but it will not prevent the decline of many species that respond to modification of terrestrial habitats as far as $1 \mathrm{~km}$ from breeding ponds. Therefore, to conserve both common and infrequently encountered pond-breeding frogs, we suggest:

(1) for common frogs (that tolerate urbanization), manage ponds to provide suitable habitat within rural and urban areas;

(2) for infrequently encountered frogs (sensitive to urbanization), maintain a connected reserve system to limit deforestation, road development and urbanization within large areas surrounding breeding ponds, and mitigate the impacts of urbanization on remaining populations (e.g., road mitigation measures); and 
(3) for all amphibians, formulate local best development practices, undertake spatial planning, and establish long-term monitoring to better integrate effective amphibian conservation practices into urban planning and land use policies. 
Acknowledgements

Martin Escobar and Kevin Mayes helped during fieldwork. Natalia Kandalaft helped with data entry. We thank Christopher MacGregor; Nicholas Dexter and Martin Fortescue [Booderee National Park]; Libby Shields and Alex Deura [NSW National Parks and Wildlife Service]; Kevin Petty [Forest Corporation NSW]; and the community of Shoalhaven for their support. Jeff Wood and Wade Blanchard made constructive comments on the experimental design and analysis. Ben Scheele, Claire Foster, Julie Watson and two anonymous reviewers made relevant comments on a previous manuscript. NRV was supported by BECAS CHILE-CONICYT [Government of Chile] during her PhD studies. NRV, DD, PG and DBL were partially funded by NERP [Australian Government]. The NSW Office of Environment and Heritage provided cartography layers. This study was conducted under Animal Ethics Approval [A2012/52]; NSW Scientific License [SL101012]; Permit for an Activity in a Commonwealth Reserve [BDR12/00010]; and Special Purpose Permit for Research in NSW State Forests granted to NRV. 


\section{Appendix A.}

Table A1

Variable estimates from the best models selected by bias corrected Akaike Information Criterion (AICc) for species richness and five individual species occurrences. Model selection was performed on Generalized Linear Models (GLMs) with a Poisson distribution (log link) for total species richness, negative binomial for species richness of infrequently encountered species, and a binomial distribution (logit link) for individual species occurrence. $\triangle$ AICc shows the difference in AICc between the current model and the model with the highest support (lowest AICc). $W$ (model weight) shows the relative probability of the model being the best model of the entire candidate set. $\left(^{*}\right)$ Model with the highest support for each response variable. Models with uninformative parameters were excluded from consideration (see Section 2). All models include intercept (number standing alone). Variables included in best models: natural logarithm of water body size=ln(water body size); square root of surface vegetation $(\%)=\sqrt{ }($ surface vegetation); first axis from metric multidimensional scaling (MDS) of terrestrial variables = MDS- 1 ; natural logarithm of road length $(\mathrm{km})$ within $1000 \mathrm{~m}$ buffer $=\ln ($ roads. $1 \mathrm{~km})$; road. $100 \mathrm{~m}=$ binary variable indicating whether $>100 \mathrm{~m}$ road length was present within $100 \mathrm{~m}$ buffer. Detailed results of model selection are shown in Supplementary material (Table S1).

\begin{tabular}{|c|c|c|c|c|c|}
\hline Response & Model (linear predictors) & $\log$ Lik & AICc & $\triangle \mathrm{AICc}$ & $w$ \\
\hline Total species richness & $0.74+0.14 \ln ($ water body size $)-0.45 \ln ($ roads. $1 \mathrm{~km})$ & -49.80 & 106.6 & * & 0.51 \\
\hline $\begin{array}{l}\text { Species richness of infrequently } \\
\text { encountered species }\end{array}$ & $\begin{array}{l}1.72+0.20 \mathrm{MDS}-1-1.13 \ln (\text { roads } .1 \mathrm{~km}) \\
2.06-1.24 \ln (\text { roads } .1 \mathrm{~km})\end{array}$ & $\begin{array}{l}-32.68 \\
-34.52\end{array}$ & $\begin{array}{l}75.1 \\
76.0\end{array}$ & 0.94 & $\begin{array}{l}0.26 \\
0.16\end{array}$ \\
\hline C. signifera & $\begin{array}{l}-3.47+0.32 \ln (\text { water body size })+0.20 \sqrt{ }(\text { surface vegetation }) \\
-2.0+0.27 \ln (\text { water body size })\end{array}$ & $\begin{array}{l}-24.79 \\
-26.35\end{array}$ & $\begin{array}{l}56.6 \\
57.2\end{array}$ & $\begin{array}{l}* \\
0.61\end{array}$ & $\begin{array}{l}0.18 \\
0.13\end{array}$ \\
\hline
\end{tabular}

\section{$\begin{array}{lllll}\text { A) Crinia signifera } & \text { B) Litoria peronii } & \text { C) Litoria fallax } & \text { D) Litoria tyleri } & \text { E) Lim. peronii }\end{array}$}
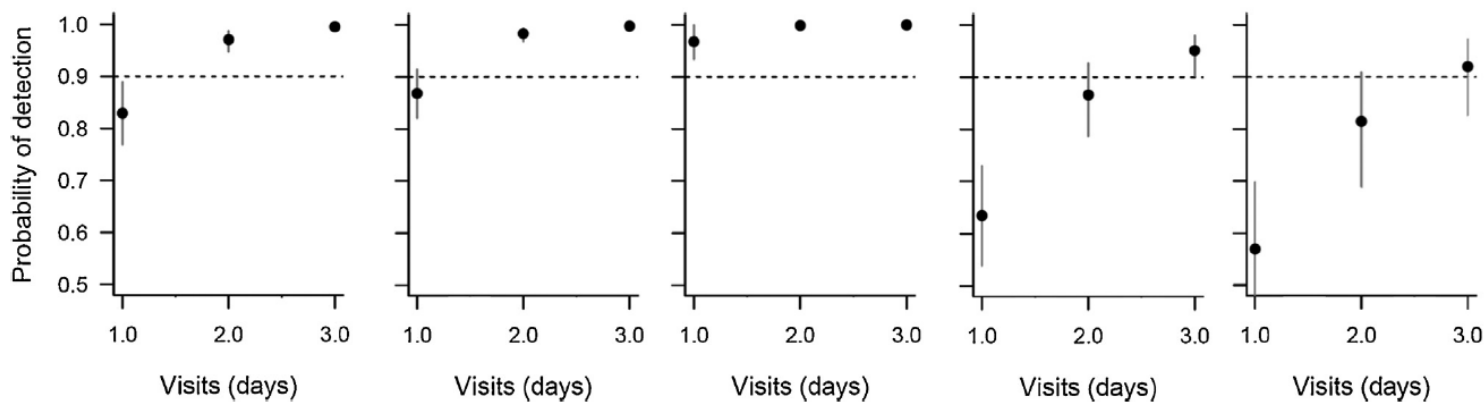

Fig. A1. Probability of detection for (A) C. signifera, (B) L. peronii, (C) L. fallax, (D) L. tyleri, and (E) Lim. peronii recorded in southeastern Australia. Estimates are based on single-visit detection probabilities from 2012 data. Vertical lines represent $95 \% \mathrm{Cl}$. After three days, all species reached 0.9 detection probability (dashed line). 
Appendix B. Supplementary data

Supplementary data associated with this article can be found, in the online version, at https://doi.org/10.1016/j.landurbplan.2016.06.006. 
References

Amphibian Research Centre. (2012). Frogs of Australia. Retrieved October 2012, from. http://frogs.org.au/frogs/of/New South Wales

Anstis, M. (2007). Tadpoles of south-eastern Australia: a guide with keys. Australia: New Holland.

Arnold, T. W. (2010). Uninformative parameters and model selection using Akaike's Information Criterion. Journal of Wildlife Management, 74(6), 1175-1178. http://dx.doi.org/10.2193/2009-367

Australian Bureau of Statistics. (2011). Census community profile. Retrieved from http://www.abs.gov.au/websitedbs/censushome.nsf/home/ communityprofiles?opendocument\&navpos=230 Accessed 26.11.14.

Baillie, J., Griffiths, J., Turvey, S., Loh, J., \& Collen, B. (2010). Evolution lost: status and trends of the world's vertebrates. United Kingdom: Zoological Society of London.

Baldwin, R. F., Calhoun, A. J. K., \& deMaynadier, P. G. (2006). The significance of hydroperiod and stand maturity for pool-breeding amphibians in forested landscapes. Canadian Journal of Zoology-Revue Canadienne De Zoologie, 84(11), 1604-1615. http://dx.doi.org/10.1139/Z06-146

Baldwin, R. F., \& deMaynadier, P. G. (2009). Assessing threats to pool-breeding amphibian habitat in an urbanizing landscape. Biological Conservation, 142(8), 1628-1638. http://dx.doi.org/10.1016/j.biocon.2009.02.039 
Barton, K. (2013). MuMIn: Multi-model inference R package version 1.9.13. Beninde, J., Veith, M., \& Hochkirch, A. (2015). Biodiversity in cities needs space: a meta-analysis of factors determining intra-urban biodiversity variation. Ecology Letters, 18(6), 581-592. http://dx.doi.org/10.1111/ele.12427

Burnham, K. P., \& Anderson, D. R. (2002). Model selection and multimodel inference: a practical information-theoretical approach (2nd ed.). New York: Springer-Verlag.

Calhoun, A. J. K., Jansujwicz, J. S., Bell, K. P., \& Hunter, M. L. (2014). Improving management of small natural features on private lands by negotiating the science-policy boundary for Maine vernal pools. Proceedings of the National Academy of Sciences of the United States of America, 111(30), 11002-11006. http://dx.doi.org/10.1073/pnas.1323606111

Calhoun, A. J. K., Nicholas, A. M., \& Klemens, M. W. (2005). Conserving pool-breeding amphibians in human-dominated landscapes through local implementation of best development practices. Wetlands Ecology and Management, 13, 291-304.

Compton, B. W., McGarigal, K., Cushman, S. A., \& Gamble, L. R. (2007). A resistant-kernel model of connectivity for amphibians that breed in vernal pools. Conservation Biology, 21(3), 788-799. http://dx.doi.org/10.1111/j. 1523-1739.2007.00674.x

Cosentino, B. J., Marsh, D. M., Jones, K. S., Apodaca, J. J., Bates, C., Beach, J., et al. (2014). Citizen science reveals widespread negative effects of roads on amphibian distributions. Biological Conservation, 180, 31-38. http://dx.doi.org/10.1016/j.biocon.2014.09.027

Department of Environment. (2013). Forest extent \& change (version 9). Australia: Department of Environment. 
Eigenbrod, F., Hecnar, S. J., \& Fahrig, L. (2008). Accessible habitat: an improved measure of the effects of habitat loss and roads on wildlife populations. Landscape Ecology, 23(2), 159_ 168. http://dx.doi.org/10.1007/s10980-007-9174-7

Ficetola, G. F., Marziali, L., Rossaro, B., De Bernardi, F., \& Padoa-Schioppa, E. (2011). Landscape-stream interactions and habitat conservation for amphibians. Ecological Applications, 21(4), 1272-1282. http://dx.doi.org/10.1890/10-0431.1

Fiske, I. J., \& Chandler, R. B. (2011). Unmarked: an R package for fitting hierarchical models of wildlife occurrence and abundance. Journal of Statistical Software, 43(10), 1-23.

Gaston, K. J., \& Fuller, R. A. (2007). Biodiversity and extinction: losing the common and the widespread. Progress in Physical Geography, 31(2), 213-225. http://dx.doi.org/10.1177/0309133307076488

Hamer, A. J., \& McDonnell, M. J. (2008). Amphibian ecology and conservation in the urbanising world: a review. Biological Conservation, 141(10), 2432-2449. http://dx.doi.org/10.1016/j.biocon.2008.07.020

Hamer, A. J., \& Parris, K. M. (2011). Local and landscape determinants of amphibian communities in urban ponds. Ecological Applications, 21(2), 378-390. http://dx.doi.org/10.1890/10-0390.1

Hanski, I. (1994). Patch-occupancy dynamics in fragmented landscapes. Trends in Ecology \& Evolution, 9(4), 131-135. http://dx.doi.org/10.1016/0169-5347(94)90177-5

Harper, E. B., Rittenhouse, T. A. G., \& Semlitsch, R. D. (2008). Demographic consequences of terrestrial habitat loss for pool-breeding amphibians: predicting extinction risks 
associated with inadequate size of buffer zones. Conservation Biology, 22(5), 12051215. http://dx.doi.org/10.1111/j. 1523-1739.2008.01015.x

Hazell, D., Cunnningham, R., Lindenmayer, D., Mackey, B., \& Osborne, W. (2001). Use of farm dams as frog habitat in an Australian agricultural landscape: factors affecting species richness and distribution. Biological Conservation, 102(2), 155-169. http://dx.doi.org/10.1016/s0006-3207(01)00096-9

Hitchings, S. P., \& Beebee, T. J. C. (1997). Genetic substructuring as a result of barriers to gene flow in urban Rana temporaria (common frog) populations: implications for biodiversity conservation. Heredity, 79, 117-127. http://dx.doi. org/10.1038/hdy.1997.134

Lauck, B. (2005). The impact of recent logging and pond isolation on pond colonization by the frog Crinia signifera. Pacific Conservation Biology, 11(1),50-56.

Lemckert, F., \& Mahony, M. (2008). Core calling periods of the frogs of temperate New South Wales, Australia. Herpetological Conservation and Biology, 3(1), 71-76.

MacKenzie, D. I., Nichols, J. D., Lachman, G. B., Droege, S., Royle, J. A., \& Langtimm, C. A. (2002). Estimating site occupancy rates when detection probabilities are less than one. Ecology, 83(8), 2248-2255. http://dx.doi.org/10.2307/3072056

McDonnell, M. J., \& Hahs, A. K. (2008). The use of gradient analysis studies in advancing our understanding of the ecology of urbanizing landscapes: current status and future directions. Landscape Ecology, 23(10), 1143-1155. http://dx. doi.org/10.1007/s10980-008-9253-4 
McDonnell, M. J., \& Hahs, A. K. (2015). Adaptation and adaptedness of organisms to urban environments. Annual Review of Ecology, Evolution, and Systematics, 46(1) http://dx.doi.org/10.1146/annurev-ecolsys-112414-054258

Parris, K. M. (2006). Urban amphibian assemblages as metacommunities. Journal of Animal Ecology, 75(3), 757-764. http://dx.doi.org/10.1111/j.1365-2656.2006.01096.x

Peduzzi, P., Concato, J., Kemper, E., Holford, T. R., \& Feinstein, A. R. (1996). A simulation study of the number of events per variable in logistic regression analysis. Journal of Clinical Epidemiology, 49(12), 1373-1379.

R Core Team. (2013). R: a language and environment for statistical computing. Vienna, Austria: R Foundation for Statistical Computing.

Rytwinski, T., \& Fahrig, L. (2015). The impacts of roads and traffic on terrestrial animal populations. In R. van der Ree, D. J. Smith, \& C. Grilo (Eds.), Handbook of road ecology (pp. 237-246). John Wiley \& Sons, Ltd.

Scheele, B., Guarino, F., Osborne, W., Hunter, D. A., Skerratt, L. F., \& Driscoll, D. A. (2014). Decline and re-expansion of an amphibian with high prevalence of chytrid fungus. Biological Conservation, 170, 86-91. http://dx.doi.org/10.1016/j. biocon.2013.12.034

Semlitsch, R. D. (2000). Principles for management of aquatic-breeding amphibians. Journal of Wildlife Management, 64(3), 615-631. http://dx.doi.org/10.2307/3802732

Semlitsch, R. D., \& Skelly, D. K. (2008). Ecology and conservation of pool-breeding amphibians. In A. J. K. Calhoun, \& P. G. deMaynadier (Eds.), Science and conservation of vernal pools in northeastern North America (pp. 127-148). CRC Press. 
Shulse, C. D., Semlitsch, R. D., \& Trauth, K. M. (2013). Mosquitofish dominate amphibian and invertebrate community development in experimental wetlands. Journal of Applied Ecology, 50(5), 1244-1256. http://dx.doi.org/10.1111/1365-2664.12126

Simon, J. A., Snodgrass, J. W., Casey, R. E., \& Sparling, D. W. (2009). Spatial correlates of amphibian use of constructed wetlands in an urban landscape. Landscape Ecology, 24(3), 361-373. http://dx.doi.org/10.1007/s10980-008-9311-y

Smallbone, L. T., Luck, G. W., \& Wassens, S. (2011). Anuran species in urban landscapes: relationships with biophysical, built environment and socio-economic factors. Landscape and Urban Planning, 101(1), 43-51. http://dx.doi.org/10.1016/j.landurbplan.2011.01.002

State of the Environment 2011 Committee. (2011). Australia state of the environment 2011. Independent report to the Australian Government Minister for Sustainability, Environment, Water, Population and Communities. Canberra: DSEWPaC.

Tyler, M. J. (1998). Australian frogs: a natural history. Cornell University Press. United Nations. (2012). World urbanization prospects, the 2011 revision: final report and tables. New York: Department of Economic and Social Affairs, Population Division.

Venables, W., \& Ripley, B. (2002). Modern applied statistics with S (4th ed.). New York: Springer.

Villaseñor, N. R., Blanchard, W., \& Lindenmayer, D. B. (2016). Decline of forest structural elements across forest-urban interfaces is stronger with high rather than low residential density. Basic and Applied Ecology, http://dx.doi.org/10.1016/j.baae.2016.03.003 
Westgate, M. J., Driscoll, D. A., \& Lindenmayer, D. B. (2012). Can the intermediate disturbance hypothesis and information on species traits predict anuran responses to fire? Oikos, 121(10), 1516-1524.

Wintle, B. A., Kavanagh, R. P., McCarthy, M. A., \& Burgman, M. A. (2005). Estimating and dealing with detectability in occupancy surveys for forest owls and arboreal marsupials. Journal of Wildlife Management, 69(3), 905-917.

Zuur, A., Ieno, E. N., Walker, N., Saveliev, A. A., \& Smith, G. M. (2009). Mixed effects models and extensions in ecology with R. Springer. 
Table 1

Aquatic and terrestrial habitat variables explored in southeastern Australia. For terrestrial variables, correlations between metric Multidimensional Scaling (MDS) axes and habitat variables are shown. MDS-1 = first axis from MDS; MDS-2 = second axis from MDS. Correlations $>0.5$ are shown in bold.

\begin{tabular}{|c|c|c|c|c|c|c|c|}
\hline \multirow[t]{3}{*}{ Type of environment } & & \multirow[t]{3}{*}{ Variable } & \multirow[t]{3}{*}{ Unit } & \multirow[t]{3}{*}{ Range } & \multirow[t]{3}{*}{ Transformation } & \multirow{2}{*}{\multicolumn{2}{|c|}{$\begin{array}{l}\text { Correlations } \\
\text { Terrestrial }\end{array}$}} \\
\hline & & & & & & & \\
\hline & & & & & & MDS-1 & MDS-2 \\
\hline Aquatic & & $\begin{array}{l}\text { water body size } \\
\text { surface vegetation } \\
\text { presence of gambusia }\end{array}$ & $\begin{array}{l}\mathrm{m}^{2} \\
\%\end{array}$ & $\begin{array}{l}2-25,213 \\
0-100 \\
0,1\end{array}$ & $\begin{array}{l}\text { ln } \\
\text { squared root }\end{array}$ & & \\
\hline \multirow[t]{2}{*}{ Terrestrial } & -landscape context & $\begin{array}{l}\text { road length within } 100 \mathrm{~m} \text { buffer } \\
\text { road length within } 1000 \mathrm{~m} \text { buffer } \\
\text { forest cover within } 100 \mathrm{~m} \text { buffer } \\
\text { forest cover within } 1000 \mathrm{~m} \text { buffer }\end{array}$ & $\begin{array}{l}\mathrm{m} \\
\mathrm{km} \\
\text { ha } \\
\text { ha }\end{array}$ & $\begin{array}{l}0-860 \\
3.4-35.5 \\
0-3.1 \\
7.1-313.1\end{array}$ & $\begin{array}{l}\text { binary }[<100, \geq 100] \\
\text { In } \\
\text { standardized } \\
\text { standardized }\end{array}$ & $\begin{array}{l}0.88 \\
0.61\end{array}$ & $\begin{array}{l}-0.06 \\
-0.6\end{array}$ \\
\hline & -habitat structure a & $\begin{array}{l}\text { al scale ( } 10 \mathrm{~m} \text { buffer) } \\
\text { fringing vegetation } \\
\text { bare ground } \\
\text { grassland } \\
\text { shrubland } \\
\text { woodland } \\
\text { forest } \\
\text { scattered trees } \\
\text { rocks }\end{array}$ & \begin{tabular}{l|l}
$\%$ & \\
$\%$ & \\
$\%$ & \\
$\%$ & \\
$\%$ & \\
$\%$ & \\
$\%$ & \\
$\%$ &
\end{tabular} & $\begin{array}{l}28-100 \\
0-65 \\
0-100 \\
0-75 \\
0-98 \\
0-100 \\
0-44 \\
0-23\end{array}$ & $\begin{array}{l}\text { standardized } \\
\text { standardized } \\
\text { standardized } \\
\text { standardized } \\
\text { standardized } \\
\text { standardized } \\
\text { standardized } \\
\text { standardized }\end{array}$ & $\begin{array}{l}\mathbf{0 . 6 2} \\
-0.25 \\
-\mathbf{0 . 6 3} \\
-0.22 \\
0.45 \\
\mathbf{0 . 6 4} \\
-0.15 \\
-0.5\end{array}$ & $\begin{array}{l}0.47 \\
-0.53 \\
\mathbf{0 . 5 5} \\
-0.3 \\
-0.3 \\
0.03 \\
0.49 \\
-0.62\end{array}$ \\
\hline
\end{tabular}


Table 2

Life history characteristics of frog species recorded in southeastern Australia, For each species, habitats, averaged numbers of eggs per female, proportion of sites where each species was recorded as present in our study and whether a species was considered common or infrequently encountered are shown. Common species allowed individual species analyses (present at $\geq 36 \%$ of ponds).

\begin{tabular}{|c|c|c|c|c|c|}
\hline Species & Common name & Habitats & $\begin{array}{l}\text { Averaged } \\
\text { no, of eggs }\end{array}$ & $\begin{array}{l}\text { Proportion } \\
\text { of sites }\end{array}$ & Type \\
\hline Grinta signtfera & Common Eastern Froglet & Widespread & 216 & 0.71 & common \\
\hline Ltorla peronti & Peron's Tree Frog & $\mathrm{F}, \mathrm{W}, \mathrm{C}, \mathrm{U}$ & 1777 & 0.71 & common \\
\hline Lmnodynastes peront1 & Brown-striped Frog & Widespread & 1319 & 0.46 & common \\
\hline Ltoria fallax & Eastern Dwarf Tree Frog & Widespread & 283 & 0.43 & common \\
\hline Litoria tylert & Tyler's Tree Frog & F,C & $>128$ & 0.36 & common \\
\hline Litoria jervistensts & Jervis Bay Tree Frog & F, H, Sw & 920 & 0.21 & infrequently encountered \\
\hline Ltorla verreauxil & Verreaux's Frog & F, H, C, near U & 725 & 0.21 & infrequently encountered \\
\hline Uperoleta sp. & - & F, W, C & $?$ & 0.18 & infrequently encountered \\
\hline Puracinta haswellt & Haswell's Froglet & W, H, S & 188 & 0.14 & infrequently encountered \\
\hline Litorla freyctnett & Freycinet's Frog & $\mathrm{H}, \mathrm{Sw}$ & 478 & 0.07 & infrequently encountered \\
\hline Limnodynastes dumerilit & Eastern Banjo Frog & F, W, H, C & 3900 & 0.04 & infrequently encountered \\
\hline Ltoria aurea & Green and Golden Bell Frog & F, W, Sw & 5121 & 0.04 & infrequently encountered \\
\hline Ltoria dentata & Bleating Tree Frog & $\mathrm{S}$ & 1070 & 0.04 & infrequently encountered \\
\hline Pseudophryne btbrontt & Bibron's Toadlet & $\mathrm{F}, \mathrm{H}, \mathrm{C}$ & 163 & 0.04 & infrequently encountered \\
\hline
\end{tabular}

Source: Anstis, 2007; Tyler, 1998.

Habitat; F-Forest; W-Woodland; H-Heathland, S-Shrubland; Sw-Swamps; C-cleared; U-Human settlements. 


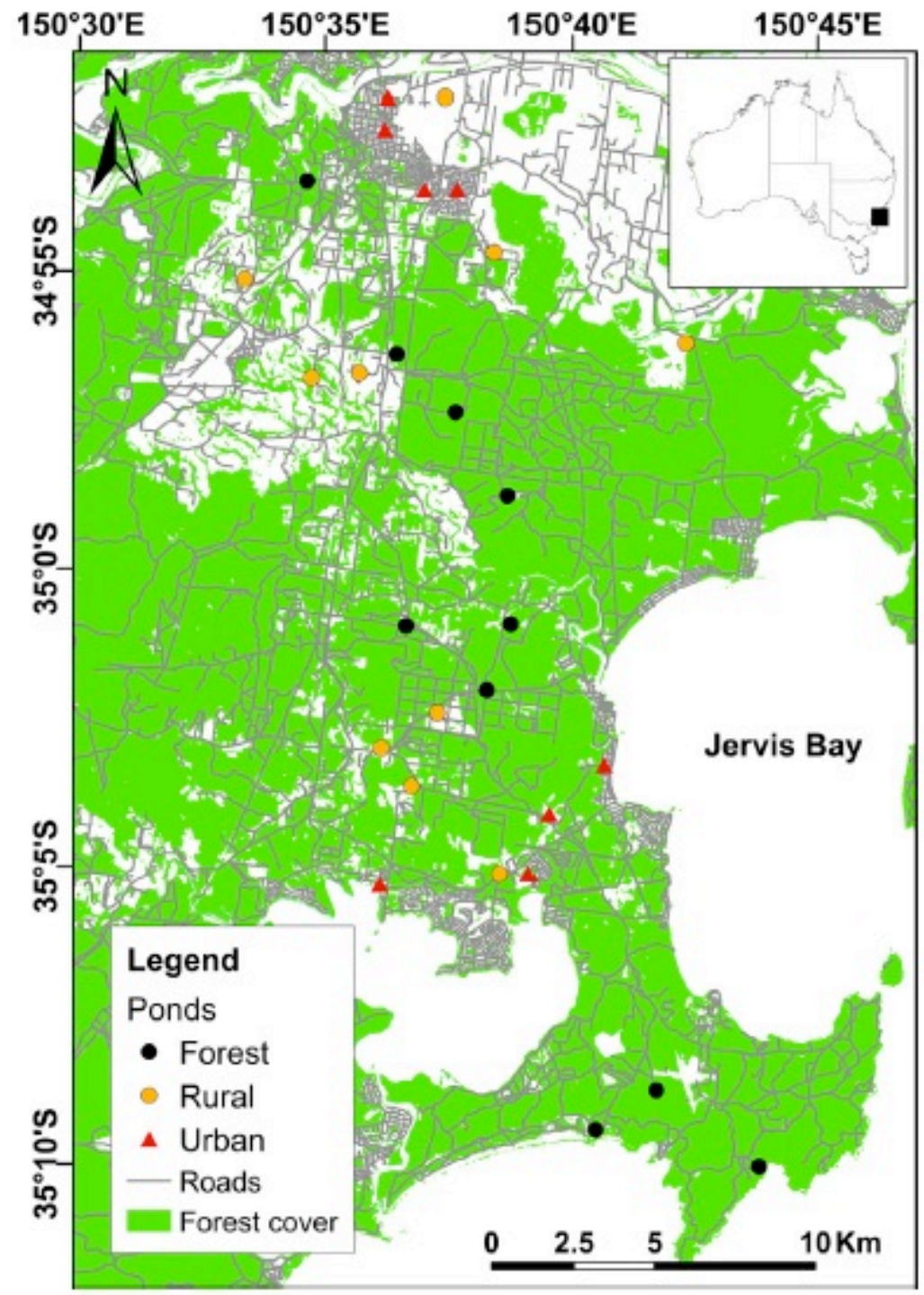

Fig. 1. Study area showing 28 surveyed ponds located in an urbanizing forested landscape in southeastern Australia, Forest cover and road network are also shown. Note that symbols representing ponds may hide the land cover type immediately surrounding a pond. 


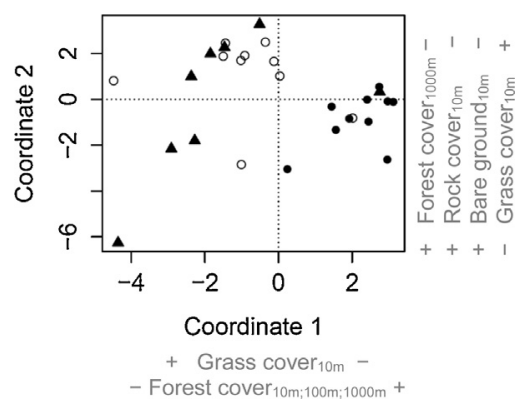

Fig. 2. Metric Multidimensional Scaling (MDS) of terrestrial variables associated to wetlands in south-eastern Australia. Symbols represent land cover type: $(\bullet)$ forests, (O) rural areas; and ( $\mathbf{\Lambda})$ urban settlements. Variables correlated ( $r>0.5)$ to each axis are shown, with subscripts representing the spatial scale. See Table 1 for details about correlations between variables. 
A) Total species richness

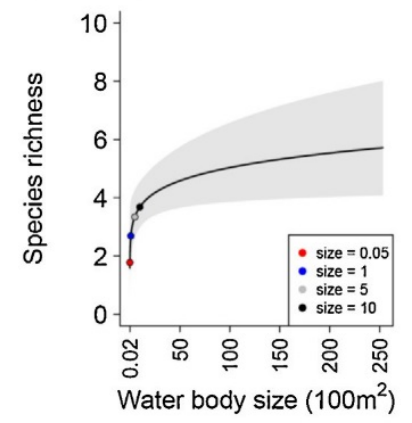

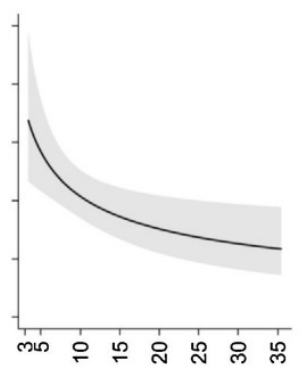

Roads within $1 \mathrm{~km}(\mathrm{~km})$
B) Species richness of infrequently encountered species

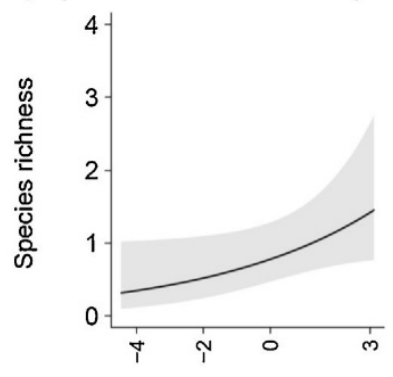

Terrestrial MDS-1

Urban - Rural - Forest

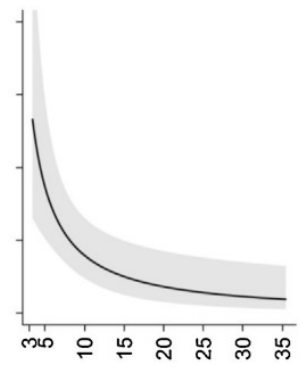

Roads within $1 \mathrm{~km}(\mathrm{~km})$
C) C. signifera

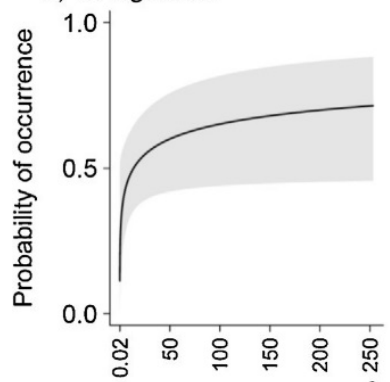

Water body size $\left(100 \mathrm{~m}^{2}\right)$

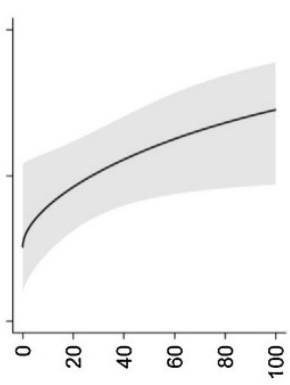

Surface vegetation (\%)
D) L. peronii

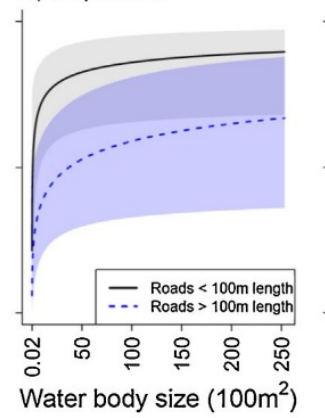

E) L. tyleri

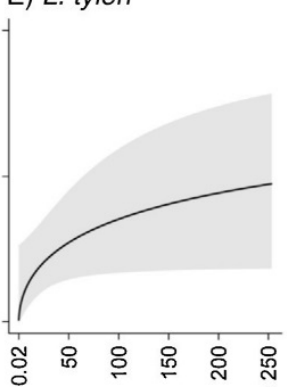

Water body size $\left(100 \mathrm{~m}^{2}\right)$
F) Lim. peronii

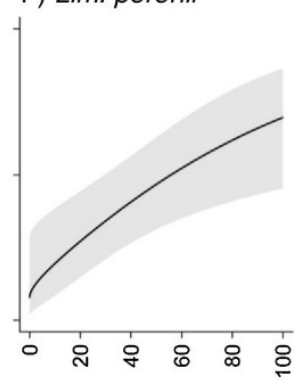

Surface vegetation (\%)

Fig. 3. Estimated species richness and individual species occurrence in Generalized Linear Models (GLMs) from model with highest support (lowest AICc). Estimated (A) total species richness in GLMs with a Poisson distribution (log link) and (B) species richness of infrequently encountered species in negative binomial GLMs. Estimated probability of occurrence for (C) C. signifera, (D) L.peronii, (E) L. tyleri, and (F) Lim. peronii in GLMs with a binomial distribution (logit link). Shadows represent confidence intervals at a 95\% confidence level. 